AKRUAL 5 (1) (2013): 26-44 $e$-ISSN: 2502-6380

\title{
AKRUAL
}

Jurnal Akuntansi

http://fe.unesa.ac.id/ojs/index.php/akrl

\section{ANALISIS RASIO-RASIO DAN UKURAN KEUANGAN, PREDIKSI FINANCIAL DISTRESS, DAN REAKSI INVESTOR}

\author{
Mekani Vestari \\ Dessy Noor Farida \\ STIE Bank BPD Jateng \\ Email: meka_vesta@yahoo.co.id \\ Artikel diterima: 17 Juli 2013 \\ Terakhir direvisi: 30 Agustus 2013
}

\begin{abstract}
The purpose of this paper is to investigate financial ratios and financial measurements that can predict financial distress. This study also examined investor reaction. To proved the effect for the long period this study not only examined the effect of independent variables per year to the prediction of financial distress, but also examined the average for five years.

Using logistic regression the results showed that there are four financial ratios that can predict financial distress. Business risk and firm size is not proven to predict financial distress. Using Kruskall-Wallis test this study also proved that investors can predict financial distress.
\end{abstract}

Keywords: financial ratios, financial measurements, financial distress, investor reaction.

\section{PENDAHULUAN}

\section{Latar Belakang Masalah}

Di tahun 2009 terdapat delapan perusahaan yang delisting dari bursa, 2010 tidak tercatat adanya perusahaan yang delisting, 2011 terdapat lima perusahaan, dan 2012 ada tiga perusahaan. Di tahun 2013 terdapat tujuh emiten terancam sanksi delisting di pasar modal oleh Bursa Efek Indonesia. Menurut Direktur Penilaian Perusahaan BEI hal tersebut akibat adanya sanksi suspensi baik di pasar reguler maupun di seluruh pasar seiring dengan rencana bisnis yang tidak jelas. Untuk menghindari delisting perseroan harus memiliki perbaikan program/rencana bisnis ke depan, seperti melakukan penawaran saham terbatas (rights issue), pergantian lini usaha, atau melakukan restrukturisasi hutang seperti yang dilakukan oleh PT. Central Proteinaprima, Tbk. Enam diantara tujuh emiten tersebut hingga akhir tahun 2013 positif delisting. Dengan demikian terjadi kenaikan perusahaan yang delisting di tahun 2013 yang sebenarnya sudah dapat diindikasi di awal tahun 2013 atau bahkan sebelumnya. 
Keputusan Direksi PT. Bursa Efek Jakarta Nomor Kep. 308/BEJ/07-2004 tentang Peraturan Nomor I-I mengenai Delisting dan Relisting Saham memberikan pedoman bagi bursa untuk melakukan delisting. Menurut aturan tersebut bursa akan menghapus pencatatan saham emiten apabila mengalami sekurang-kurangnya kondisi atau peristiwa, yang secara signifikan berpengaruh negatif terhadap kelangsungan usaha, baik secara finansial atau secara hukum, atau terhadap kelangsungan status emiten sebagai perusahaan terbuka, dan tidak dapat menunjukkan indikasi pemulihan yang memadai. Kondisi lainnya yang dapat menyebabkan delisting adalah saham emiten yang akibat suspensi di Pasar Reguler dan Pasar Tunai, hanya diperdagangkan di Pasar Negosiasi sekurang-kurangnya selama 24 bulan terakhir. Aturan tersebut menunjukkan bahwa adanya masalah terhadap kelangsungan usaha yang ditandai dengan kesulitan keuangan (financial distress) yang selanjutnya tidak menunjukkan indikasi pemulihan yang memadai, yang mengarah kepada kondisi kebangkrutan, merupakan salah satu faktor utama bagi perusahaan untuk di-delisting.

Financial distress merupakan tahap penurunan kondisi keuangan sebelum terjadinya kebangkrutan (Platt dan Platt, 2002 dalam Ramadhani dan Lukviarman, 2009). Kesulitan keuangan merupakan suatu kondisi yang sulit untuk didefinisikan. Kondisi ini bisa bermula dari ketidakmampuan perusahaan dalam mengelola perusahaan sehingga mengakibatkan kerugian operasional maupun kerugian bersih tahun berjalan dan atau aliran kas operasi yang lebih kecil dibandingkan dengan laba operasinya. Apabila kondisi ini tidak dapat dipulihkan akan mengganggu komponen ekuitas dan kemampuan perusahaan dalam memenuhi kewajiban jangka panjang, bahkan jangka pendeknya. Dengan demikian, kesulitan keuangan dapat dilihat sebagai kontinum jangka panjang, mulai dari yang ringan sampai yang paling berat (Hanafi dan Halim, 2007).

Analisis terhadap financial distress menjadi hal penting, baik bagi pihak manajemen perusahaan maupun stakeholder. Kemampuan mengindikasi kondisi financial distress memungkinkan perusahaan dapat melakukan antisipasi melalui berbagai program/rencana bisnis untuk meminimalkan dampak dan bahkan keluar dari masalah tersebut. Bagi stakeholder indikasi terhadap kondisi financial distress akan membantu dalam pengambilan keputusan yang tepat terkait dengan perusahaan untuk meminimalkan risiko. Hal ini mengingat stakeholder, terutama para investor dan kreditur sebagai penerima risiko terbesar dalam kasus financial distress.

Hampir semua studi mengenai kebangkrutan, ukuran maupun rasio keuangan memainkan peran yang dominan di hampir semua variabel yang digunakan sebagai prediktor. Hal ini membuktikan fakta bahwa rasio memberikan kontribusi yang besar untuk memahami kinerja keuangan perusahaan dan status keuangan masa depan (Yap, et. al., 2012). Penelitian terkait dengan prediksi financial distress dan kebangkrutan dengan menggunakan rasio-rasio keuangan sebagai prediktor telah banyak dilakukan. Penelitian dengan menggunakan model multivariat pertama dilakukan oleh Altman (1968) yang menghasilkan nilai Z-Score untuk memprediksi financial distress. Model ini selanjutnya diperbaiki kembali sehingga menghasilkan Model Altman Modifikasi di tahun 1995. Model Altman Modifikasi melibatkan rasio 
keuangan likuiditas, struktur keuangan, dan efisiensi manajemen untuk memprediksi financial distress. Penelitian yang dilakukan Yap, et. al. (2012) di Malaysia menggunakan 16 rasio keuangan dan menunjukkan bahwa rasio-rasio retained earnings to total assets, cash flows to total debts, cash to current liabilities, dan total debts to total assest berpengaruh terhadap perusahaan yang di-delisting. Penelitian Terzi, et. al. (2012) di Turki menggunakan 27 rasio keuangan dan menunjukkan bahwa assets turnover, equity to total assets, retained earnings to total assets, dan working capital to total assets berpengaruh terhadap prediksi financial distress yang diukur dengan menggunakan model Altman Z-Score.

Penelitian di Indonesia yang dilakukan oleh Almilia dan Kristijadi (2003) menggunakan 19 rasio keuangan menurut Platt dan Platt (2002) dan menunjukkan bahwa rasio net income to sales, current liabilities to total assets, current assets to current liabilities, dan growth net income to total assets berpengaruh terhadap prediksi financial distress yang diukur dengan menggunakan kriteria laba operasi negatif dua tahun dan tidak membagi dividen lebih dari satu tahun. Penelitian yang dilakukan Brahmana dengan periode penelitian 2000-2003 menunjukkan hanya total assets yang berpengaruh terhadap perusahaan yang di-delisting. Penelitian Yuanita (2010) menunjukkan bahwa rasio current assets to current liabilities, net income to sales, current liabilities to total assets, dan growth net income to total assets berpengaruh terhadap prediksi financial distress yang diukur dengan menggunakan kriteria laba bersih dan ROE negatif, tidak membayar dividen lebih dari satu tahun. Penelitian Kamaludin dan Pribadi (2011) menunjukkan bahwa hanya rasio debts to equity yang berpengaruh terhadap prediksi financial distress yang diukur dengan menggunakan Altman Z-Score.

Penelitian ini bertujuan untuk menginvestigasi bahwa rasio-rasio dan ukuran keuangan dapat digunakan untuk memprediksi financial distress. Variabel independen sebagai prediktor mengacu kepada rasio-rasio keuangan yang digunakan dalam penelitian Yap, et. al. (2012). Selanjutnya untuk menentukan rasio-rasio keuangan yang akan digunakan dilakukan uji ANOVA untuk mendapatkan rasiorasio keuangan yang secara signifikan berbeda antara perusahaan yang diprediksi distress dengan yang tidak. Variabel dependen menggunakan Altman Z-Score, mengacu kepada penelitian Kamaludin dan Pribadi (2011). Penelitian ini akan menambahkan variabel prediktor lain yakni risiko bisnis dengan pertimbangan bahwa tingkat risiko perusahaan akan berdampak terhadap risiko kebangkrutan. Perusahaan besar akan memiliki tingkat risiko kebangkrutan yang berbeda dengan perusahaan kecil. Oleh karena itu untuk mengendalikan ukuran perusahaan maka di dalam persamaan juga akan memasukkan variabel tersebut.

Analisis fundamental merupakan salah satu analisis yang seharusnya dilakukan oleh investor sebelum mengambil keputusan investasi. Perusahaan yang diprediksi mengalami kesulitan keuangan akan direaksi negatif oleh investor, demikian pula sebaliknya. Oleh karena itu penelitian ini juga bertujuan untuk menginvestigasi bahwa investor mampu memprediksi financial distress perusahaanperusahaan yang go public. 
Periode penelitian meliputi jangka waktu lima tahun dari 2007 hingga 2012 untuk melihat pengaruh variabel-variabel independen terhadap prediksi financial distress. Kondisi financial distress merupakan dampak dari kinerja keuangan yang harus ditinjau dalam jangka panjang. Menurut Almilia dan Kristijadi (2003) prediksi akan lebih baik jika data series cukup panjang. Berbagai penelitian yang sudah dilakukan hanya melihat dampak kinerja keuangan per tahunnya terhadap periode prediksi. Oleh karena itu penelitian ini tidak hanya menguji pengaruh rasio-rasio keuangan perusahaan per tahunnya terhadap prediksi financial distress, namun juga menguji pengaruh rata-rata rasio keuangan selama lima tahun terhadap prediksi financial distress untuk menunjukkan dampak kinerja keuangan dalam jangka panjang. Objek penelitian menggunakan perusahaan manufaktur karena sektor ini memiliki jumlah emiten terbesar. Hal ini juga mengingat bahwa rasio dominan yang berpengaruh akan berbeda untuk sektor industri yang berbeda (Yap, et. al., 2012).

\section{Perumusan Masalah}

Berdasarkan latar belakang masalah tersebut di atas, maka dapat dirumuskan masalah penelitian sebagai berikut:

1. Apakah rasio-rasio dan ukuran keuangan dapat digunakan untuk memprediksi financial distress?

2. Apakah terdapat perbedaan reaksi investor terhadap hasil prediksi financial distress?

\section{Tujuan Penelitian}

Tujuan dari penelitian ini adalah untuk:

1. Menginvestigasi bahwa rasio-rasio keuangan berpengaruh positif/negatif terhadap prediksi financial distress.

2. Menginvestigasi bahwa risiko bisnis berpengaruh positif terhadap prediksi financial distress.

3. Menginvestigasi bahwa ukuran perusahaan berpengaruh negatif terhadap prediksi financial distress.

4. Menginvestigasi bahwa reaksi investor akan berbeda terhadap hasil prediksi financial distress.

\section{KAJIAN PUSTAKA}

\section{Financial Distress}

Financial distress terjadi sebelum kebangkrutan benar-benar dialami oleh perusahaan. Kondisi ini terjadi ketika terdapat masalah likuiditas yang sangat parah yang tidak dapat dipecahkan tanpa perubahan ukuran dari operasi atau struktur perusahaan (Platt dan Platt, 2002 dalam Ramadhani dan Lukviarman, 2009). Beaver (1966) dalam Terzi, et. al. (2012) mendefinisikan kondisi ini sebagai ketidakmampuan perusahaan untuk memenuhi kewajiban keuangan (kebangkrutan) atau perusahaan memiliki kesulitan di dalam membayar kewajibannya. 
Menurut Atmini (2005) dalam Kamaludin dan Pribadi (2011), financial distress adalah konsep luas yang terdiri atas beberapa situasi dimana suatu perusahaan menghadapi masalah kesulitan keuangan. Istilah umum untuk menggambarkan situasi tersebut adalah kebangkrutan, kegagalan, ketidakmampuan melunasi hutang, dan default. Ketidakmampuan melunasi hutang menunjukkan kinerja negatif dan adanya masalah likuiditas. Default berarti suatu perusahaan melanggar perjanjian dengan kreditur dan dapat menyebabkan tindakan hukum. Dengan demikian kesehatan suatu perusahaan dapat digambarkan dari titik sehat yang paling ekstrim sampai ke titik tidak sehat yang paling ekstrim. Kesulitan keuangan jangka pendek bersifat sementara dan belum begitu parah. Namun kesulitan semacam ini apabila tidak ditangani dapat berkembang menjadi kesulitan tidak solvabel. Jika tidak solvabel, perusahaan bisa dilikuidasi atau direorganisasi. Likuidasi dipilih apabila nilai likuidasi lebih besar dibandingkan dengan nilai perusahaan jika diteruskan. Reorganisasi dipilih apabila perusahaan masih menunjukkan prospek dan dengan demikian nilai perusahaan jika diteruskan lebih besar dibandingkan nilai perusahaan kalau dilikuidasi.

\section{Prediksi Financial Distress}

Model pertama yang dikembangkan di dalam prediksi financial distress adalah model univariat oleh FitzPatrick, Winakor dan Smith di tahun 1930 (Yap, et. al., 2012), dan Mervin di tahun 1942 (Yap, et. al., 2012). Model yang paling dikenal adalah yang dikembangkan oleh Beaver, 1966 (Yap, et. al., 2012).

Prediksi financial distress dengan menggunakan model univariat ini memiliki berbagai kelemahan. Altman (1968) menyatakan bahwa salah satu kelemahan utama model ini adalah tidak memungkinkannya rasio-rasio keuangan yang digunakan untuk berinteraksi satu dengan lainnya karena masing-masing rasio diuji secara terpisah, diisolasikan dari rasio lainnya. Model ini menghasilkan suatu penilaian terhadap prediksi financial distress hanya dari satu sudut pandang.

Untuk mendapatkan penilaian yang bersifat lebih komprehensif, mengacu kepada berbagai rasio keuangan, maka dikembangkan model multivariat yang pertama oleh Altman (1968). Model ini dilakukan dengan menggunakan analisis diskriminan dan menghasilkan nilai Z-Score yang merupakan indeks keseluruhan fungsi multiple discriminant analysis. Rasio-rasio keuangan yang dipertimbangkan meliputi working capital to total assets, retained earnings to total assets, earnings before interest and taxes to total assets, market value of equity to book value of total debts, dan sales to total assets. Terdapat angka-angka cut off nilai $\mathrm{Z}$ yang dapat menjelaskan apakah perusahaan akan mengalami kegagalan atau tidak dimasa mendatang dengan membagi ke dalam tiga kategori, yakni perusahaan yang tidak sehat, masuk grey area, dan perusahaan yang sehat.

Model pertama yang dikembangkan Altman ini mengalami suatu revisi. Penyesuaian ini dilakukan agar model prediksi dapat juga diaplikasikan untuk perusahaan-perusahaan privat. Hal ini dilakukan dengan mengganti market value of equity menjadi book value of equity. Seiring berjalannya waktu dan penyesuaian 
terhadap berbagai jenis perusahaan, Altman melakukan modifikasi model agar dapat diterapkan pada semua perusahaan, seperti manufaktur, non manufaktur, dan perusahaan penerbit obligasi di negara berkembang. Dalam Z-Score modifikasi ini, Altman mengeliminasi variabel sales to total assets karena rasio ini sangat bervariatif pada industri dengan ukuran aset yang berbeda.

Model prediksi kebangkrutan lainnya dikembangkan oleh Springate dan Zmijewski. Model Springate dikembangkan oleh Springate, 1978 (dalam Ramadhani dan Lukviarman, 2009) dengan menggunakan analisis multidiskriminan. Model ini dapat digunakan untuk memprediksi kebangkrutan dengan tingkat keakuratan 92,5\%. Model Zmijewski, 1984 (dalam Ramadhani dan Lukviarman, 2009) menggunakan analisis rasio yang mengukur kinerja, leverage, dan likuiditas suatu perusahaan untuk model prediksinya. Zmijewski menggunakan probit analisis yang diterapkan pada 40 perusahaan yang telah bangkrut dan 800 perusahaan yang masih bertahan saat itu.

\section{Rasio-rasio Keuangan, Ukuran Keuangan, dan Reaksi Investor}

Rasio keuangan pada dasarnya disusun dengan menggabungkan angka-angka di dalam atau antara laporan laba rugi dan laporan posisi keuangan. Kelebihan analisis dengan menggunakan rasio ini adalah dapat menghilangkan pengaruh perbedaan ukuran dan membuat ukuran bukan dalam angka absolut, namun dalam angka relatif.

Analisis rasio dapat dikelompokkan ke dalam lima macam kategori (Hanafi dan Halim, 2007), yakni :

1. Rasio likuiditas, mengukur kemampuan perusahaan dalam memenuhi kewajiban jangka pendeknya.

2. Rasio aktivitas, mengukur sejauhmana efektivitas penggunaan aset dengan melihat tingkat aktivitas aset.

3. Rasio solvabilitas, mengukur sejauhmana kemampuan perusahaan dalam memenuhi kewajiban jangka panjangnya.

4. Rasio profitabilitas, melihat kemampuan perusahaan dalam menghasilkan laba.

5. Rasio pasar, melihat perkembangan nilai perusahaan relatif terhadap nilai bukunya.

Kelima rasio tersebut ingin melihat prospek dan risiko perusahaan di masa mendatang. Risiko bisnis perusahaan dapat ditinjau dari variabilitas rasio profitabilitas. Semakin tinggi variabilitas rasio profitabilitasnya semakin berisiko bisnis tersebut, demikian pula sebaliknya. Faktor prospek dalam rasio tersebut akan mempengaruhi harapan investor terhadap perusahaan pada masa-masa mendatang. Dengan mempertimbangkan berbagai rasio keuangan perusahaan, investor dapat melakukan prediksi terhadap adanya financial distress. Hasil prediksi ini akan berdampak terhadap perbedaan reaksi investor yang dapat diukur dengan menggunakan harga saham, return saham, maupun abnormal return. 


\section{PENGEMBANGAN HIPOTESIS}

Berdasarkan latar belakang masalah dan rumusan masalah, maka dapat dirumuskan hipotesis sebagai berikut :

$\mathrm{H}_{1}=$ Rasio-rasio keuangan berpengaruh positif/negatif terhadap prediksi financial distress.

$\mathrm{H}_{2}=$ Risiko bisnis berpengaruh positif terhadap prediksi financial distress.

$\mathrm{H}_{3}=$ Ukuran perusahaan berpengaruh negatif terhadap prediksi financial distress.

$\mathrm{H}_{4}=$ Reaksi investor akan berbeda terhadap hasil prediksi financial distress.

\section{METODE PENELITIAN}

\section{Populasi dan Sampel}

Populasi dalam penelitian ini adalah perusahaan manufaktur yang terdaftar di Bursa Efek Indonesia. Teknik pengambilan sampel dilakukan dengan metode purposive sampling dengan kriteria sebagai berikut:

1. Perusahaan manufaktur terdaftar di Bursa Efek Indonesia per 1 Januari 2007 - 2 Januari 2013.

2. Menerbitkan laporan keuangan tahunan dalam mata uang rupiah yang tersedia pada Indonesian Capital Market Directory (ICMD) atau melalui www.idx.co.id dan memiliki informasi harga saham (closing price) tanggal 2 Januari 2013.

3. Hasil penilaian prediksi financial distress-nya tidak masuk ke dalam kriteria grey area.

\section{Definisi Konsep dan Operasional Variabel}

Definisi konsep dan operasional dari variabel yang digunakan, meliputi:

1. Prediksi financial distress.

Definisi financial distress menurut Platt dan Platt (2002) dalam Ramadhani dan Lukviarman (2009) adalah terdapatnya masalah likuiditas yang sangat parah yang tidak dapat dipecahkan tanpa perubahan ukuran dari operasi atau struktur perusahaan. Menurut Beaver (1966) dalam Terzi, et. al. (2012), financial distress adalah ketidakmampuan perusahaan untuk memenuhi kewajiban keuangan (kebangkrutan) atau perusahaan memiliki kesulitan di dalam membayar kewajibannya. Menurut Atmini (2005) dalam Kamaludin dan Pribadi (2011), financial distress adalah konsep luas yang terdiri atas beberapa situasi dimana suatu perusahaan menghadapi masalah kesulitan keuangan.

Definisi operasional untuk prediksi financial distress menggunakan Model Altman Modifikasi (1995) sebagai berikut :

$$
Z "=-6,56 X_{1}+3,26 X_{2}+6,72 X_{3}+1,05 X_{4}
$$

Dimana,

Z" : bankrupcy index.

$\mathrm{X}_{1}$ : working capital / total assets.

$\mathrm{X}_{2}$ : retained earnings / total assets. 
$\mathrm{X}_{3}:$ EBIT / total assets.

$\mathrm{X}_{4}$ : book value of equity / book value of total debt.

Klasifikasi perusahaan yang sehat dan tidak sehat didasarkan pada nilai $\mathrm{Z}$ score berikut:

a. Jika nilai Z" $<1,1$ maka termasuk perusahaan yang tidak sehat.

b. Jika nilai $1,1<Z$ " $<2,6$ maka termasuk grey area (tidak dapat ditentukan apakah perusahaan sehat ataupun tidak sehat).

c. Jika nilai Z" > 2,6 maka termasuk perusahaan yang sehat.

Perusahaan yang hasil penilaian Z" score-nya masuk kriteria a diberi kode 1 dan perusahaan yang masuk kriteria c diberi kode 0 .

2. Rasio-rasio keuangan.

Rasio-rasio keuangan menurut Hanafi dan Halim (2007) pada dasarnya disusun dengan menggabungkan angka-angka di dalam atau antara laporan laba rugi dan laporan posisi keuangan. Dalam penelitian berbagai rasio keuangan mengacu penelitian Yap, et. al. (2012), yang sering digunakan dalam prediksi financial distress dan memiliki hasil signifikan. Rasio-rasio keuangan tersebut adalah sebagai berikut :

a. Rasio profitabilitas : net income to total assets (NITA), retained earnings to total assets (RETA), EBIT to total assets (EBITTA), dan net income to sales (NIS).

b. Rasio likuiditas : current assets to current liabilities (CACL), working capital to total assets (WCTA), market value equity to total debt (METD), cash flows to total debt (CFTD), cash to sales (CS), current assets to total assets (CATA), working capital to sales (WCS), cash to current liabilities (CCL), dan funds flow to total liabilities (FFTL).

c. Rasio solvabilitas : total debts to total assets (TDTA).

d. Rasio efisiensi : debtors turnover (debtor), sales to total assets (STA).

3. Risiko Bisnis.

Risiko bisnis merupakan ketidakpastian yang dihadapi perusahaan dalam menjalankan kegiatan bisnisnya (Hardianti dan Gunawan, 2010). Dalam menilai risiko bisnis Brigham dan Houston (2001) menggunakan ukuran variabilitas. Dalam penelitian ini menggunakan nilai standar deviasi dari profitabilitas, yakni ROA lima tahun sebelum prediksi.

4. Ukuran perusahaan.

Ukuran perusahaan merupakan nilai dari sebuah perusahaan yang dapat menunjukkan besar kecilnya perusahaan. Besar kecilnya perusahaan dapat diukur berdasarkan total penjualan, total nilai buku aset, nilai bersih kekayaan, dan jumlah tenaga kerja (Parwati dan Suhardjo, 2009). Ukuran perusahaan diukur menggunakan Total Aset dengan variabel dummy. Diberi kode 1 jika nilai Ln Total Aset > median Ln Total Aset industri, kode 0 untuk sebaliknya. 


\section{Reaksi Investor.}

Reaksi investor menunjukkan respon investor terhadap suatu informasi yang diperoleh. Respon investor diukur dengan menggunakan closing price harga saham 2 Januari 2013.

\section{Model Analisis}

Model analisis statistik yang digunakan dalam penelitian ini adalah model regresi logistik dalam memprediksi kondisi financial distress dengan menggunakan indikator rasio-rasio dan ukuran keuangan. Persamaan untuk regresi logistik yang digunakan :

$$
\mathrm{Z}_{\mathrm{i}}=\alpha+\beta_{1} \mathrm{X}_{1}+\beta_{2} \mathrm{X}_{2}+\beta_{3} \mathrm{X}_{3}+\ldots+\beta_{\mathrm{n}} \mathrm{X}_{\mathrm{n}}+\varepsilon
$$

$\mathrm{Z}_{\mathrm{i}}$ merupakan prediksi financial distress, sedangkan $\mathrm{X}_{1}$ hingga $\mathrm{X}_{\mathrm{n}}$ adalah variabelvariabel independen yang digunakan berupa rasio-rasio keuangan, risiko bisnis, dan ukuran perusahaan.

\section{Teknik Analisis Data}

Sebelum melakukan pengujian dengan berbagai alat analisis, disajikan deskripsi terhadap berbagai variabel yang digunakan. Statistik deskriptif memberikan gambaran atau deskripsi suatu data yang ditinjau dari nilai minimum dan maksimum. Nilai modus digunakan untuk memberikan deskripsi terhadap variabel dummy.

Untuk menguji adanya perbedaan signifikan antara berbagai rasio keuangan dan reaksi investor yang dikelompokkan ke dalam perusahaan yang diprediksi mengalami financial distress dan yang tidak, dilakukan uji ANOVA dengan menggunakan independent samples $t$ test. Jika syarat-syarat untuk melakukan uji tersebut tidak terpenuhi maka digunakan Uji Kruskal Wallis.

Untuk menguji pengaruh rasio-rasio dan ukuran keuangan terhadap prediksi financial distress digunakan model regresi logistik melalui metode stepwise dengan tahapan langkah sebagai berikut:

1. Uji Hosmer dan Lemeshow.

Menilai apakah model regresi layak digunakan untuk memprediksi, dengan melihat kriteria nilai tingkat signifikansi Chi Square Hosmer and Lemeshow > taraf signifikansi 5\%.

2. Uji koefisien determinasi Nagelkerke's R Square $\left(\mathrm{R}^{2}\right)$.

Melihat pengaruh atau besarnya kontribusi dari variabel independen terhadap variabel dependen dalam model penelitian.

3. Pengujian hipotesis penelitian.

Dilakukan dengan melihat nilai Wald Test dan tingkat signifikansi masing-masing variabel independen pada taraf keyakinan 5\%. Jika nilai tingkat signifikansi Wald Test $>$ taraf keyakinan 5\%, maka terdapat pengaruh signifikan atau dapat digunakan sebagai prediktor bagi prediksi financial distress dimana $\mathrm{H}_{0}$ ditolak. 


\section{HASIL PENELITIAN DAN PEMBAHASAN Penentuan Sampel}

Pada tahapan awal diperoleh sampel sebanyak 161 perusahaan manufaktur yang terdaftar di Bursa Efek Indonesia dalam periode 1 Januari 2007-2 Januari 2013. Dari 161 perusahaan tersaring 104 perusahaan yang menerbitkan laporan keuangan tahunan dalam mata uang rupiah dan memiliki informasi terkait dengan harga saham (closing price) per 2 Januari 2013. Jumlah sampel akhir yang diperoleh sebanyak 72 perusahaan karena terdapat 32 perusahaan yang memiliki perhitungan nilai prediksi financial distress yang masuk dalam kriteria grey area.

\section{Statistik Deskriptif}

Pada tabel 1 disajikan data mengenai nilai minimum dan maksimum berbagai rasio keuangan, risiko bisnis, dan ukuran perusahaan. Untuk closing price per 2 Januari 2013 terendah sebesar Rp50,00 dimiliki oleh PT. Davomas Abadi, Tbk. dan PT. Indo Acidatama, Tbk. Sementara closing price tertinggi sebesar Rp740.000,00 milik PT. Multi Bintang Indonesia, Tbk.

Tabel 1. Statistik Deskritif Rasio-rasio Keuangan, Risiko Bisnis, dan Ukuran Perusahaan

\begin{tabular}{clcccccc}
\hline No. & Variabel & Minimum & Emiten & Tahun & Maksimum & Emiten & Tahun \\
\hline 1. & NITA & $-0,7558$ & AKKU & 2011 & 1,5200 & DPNS & 2010 \\
2. & RETA & $-2,7027$ & BIMA & 2010 & 1,5865 & JKSW & 2010 \\
3. & EBITTA & $-0,6734$ & SIMA & 2011 & 2,2280 & DPNS & 2010 \\
4. & NIS & $-9,3952$ & SIMA & 2011 & 0,7821 & ERTX & 2011 \\
5. & CACL & 0,1527 & LAPD & 2011 & 113,7159 & DAVO & 2009 \\
6. & WCTA & $-1,3425$ & INTD & 2007 & 4,2020 & BUDI & 2007 \\
7. & METD & 0,0024 & BATA & 2007 & 80,9176 & DPNS & 2011 \\
8. & CFTD & $-3,9372$ & BTON & 2009 & 10,3297 & INTP & 2010 \\
9. & CS & 0,0004 & LPIN & 2007 & 1,4465 & DAVO & 2009 \\
10. & CATA & 0,0297 & LAPD & 2011 & 4,4797 & BUDI & 2007 \\
11. & WCS & $-15,6672$ & SIMA & 2010 & 4,6232 & BUDI & 2007 \\
12. & CCL & 0,0003 & LPIN & 2007 & 91,4368 & DAVO & 2009 \\
13. & FFTL & $-3,9372$ & BTON & 2009 & 10,3297 & INCI & 2010 \\
14. & TDTA & 0,0413 & INCI & 2010 & 3,2100 & BIMA & 2010 \\
15. & DEBTOR & 0,0000 & & ALL & 2,0000 & DAVO & 2010 \\
16. & STA & 0,0321 & SIMA & 2009 & 5,7339 & DPNS & 2010 \\
17. & RISIKO & 20,2285 & TIRA & 2009 & 29,4530 & ASII & 2011 \\
18. & UKURAN & 0,0000 & & ALL & 1,0000 & & ALL \\
\hline S
\end{tabular}

Sumber: data sekunder diolah, $2007-2011$

\section{Hasil Uji Normalitas Rasio-rasio Keuangan}

Hasil uji menunjukkan terdapat sepuluh variabel yang konsisten tidak normal, meliputi RETA, NIS, CACL, METD, CFTD, CS, WCS, CCL, FFTL, dan TDTA. Berikut hasil uji normalitas terhadap rasio-rasio keuangan dari tahun 2007 sampai dengan 2011 serta rasio keuangan rata-rata selama lima tahun tersebut. 
Tabel 2. Hasil Uji Normalitas Rasio-Rasio Keuangan

\begin{tabular}{|c|c|c|c|c|c|c|}
\hline \multirow[t]{2}{*}{ No. } & \multirow[t]{2}{*}{ Rasio } & \multicolumn{5}{|c|}{ Periode } \\
\hline & & 2007 & 2009 & 2010 & 2011 & Rata2 \\
\hline 1. & NITA & & & & & \\
\hline 2. & RETA & & & & & \\
\hline 3. & EBITTA & & & & & \\
\hline 4. & NIS & & & & & \\
\hline 5. & CACL & & & & & \\
\hline 6. & WCTA & & & & & \\
\hline 7. & METD & & & & & \\
\hline 8. & CFTD & & & & & \\
\hline 9. & $\mathrm{CS}$ & & & & & \\
\hline 10. & CATA & & & & & \\
\hline 11. & WCS & & & & & \\
\hline 12. & CCL & & & & & \\
\hline 13. & FFTL & & & & & \\
\hline 14. & TDTA & & & & & \\
\hline 15. & Debtor & & & & & \\
\hline 16. & STA & & & & & \\
\hline \multicolumn{7}{|c|}{ Keterangan : } \\
\hline & & Normal & & & T. & nal \\
\hline
\end{tabular}

Sumber: data sekunder diolah, 2007 - 2011

\section{Hasil Uji Beda Rasio-Rasio Keuangan}

Berikut hasil uji beda terhadap rasio-rasio keuangan dari tahun 2007 sampai dengan 2011 serta rasio keuangan rata-rata selama lima tahun tersebut.

Tabel 3. Hasil Uji Beda Rasio-Rasio Keuangan

\begin{tabular}{|c|c|c|c|c|c|c|c|}
\hline \multirow{2}{*}{ No. } & \multirow{2}{*}{ Rasio } & \multicolumn{6}{|c|}{ Periode } \\
\hline & & 2007 & 2008 & 2009 & 2010 & 2011 & Rata2 \\
\hline 1. & NITA & & & & & & \\
\hline 2. & RETA & & & & & & \\
\hline 3. & EBITTA & & & & & & \\
\hline 4. & NIS & & & & & & \\
\hline 5. & CACL & & & & & & \\
\hline 6. & WCTA & & & & & & \\
\hline 7. & METD & & & & & & \\
\hline 8. & CFTD & & & & & & \\
\hline 9. & $\mathrm{CS}$ & & & & & & \\
\hline 10. & CATA & & & & & & \\
\hline 11. & WCS & & & & & & \\
\hline
\end{tabular}




$\begin{array}{ll}\text { 12. } & \text { CCL } \\ \text { 13. } & \text { FFTL } \\ \text { 14. } & \text { TDTA } \\ \text { 15. } & \text { Debtor } \\ \text { 16. } & \text { STA }\end{array}$

Keterangan :

\begin{tabular}{lll}
$:$ Berbeda & $:$ Tidak berbeda \\
\hline
\end{tabular}

Sumber: data sekunder diolah, 2007-2011

\section{Hasil Uji Regresi Logistik Tahun 2007}

Hasil uji Hosmer dan Lemeshow menunjukkan angka di atas 0,05. Dengan demikian data empiris sama dengan model atau model dikatakan fit sehingga dapat diterima. Nilai Nagelkerke R Square menunjukkan angka 0,6. Dengan demikian variabilitas variabel dependen yang dapat dijelaskan oleh variabilitas variabel independen sebesar $60 \%$. Tabel berikut menunjukkan hasil pengujian tersebut.

\section{Tabel 4. Uji Hosmer dan Lemeshow}

\begin{tabular}{ll}
\hline \multicolumn{1}{c}{ Keterangan } & Hasil \\
\hline Nilai Sig. Uji Hosmer dan Lemeshow & 0,883 \\
Nagelkerke R Square & 0,600 \\
\hline
\end{tabular}

Sumber: data sekunder diolah, 2007-2012

Pengujian hipotesis dilakukan dengan melihat hasil yang terdapat dalam Variable in the Equation. Variabel EBITTA dan TDTA signifikan pada 0,05. Semakin tinggi nilai EBITTA maka probabilitas perusahaan mengalami financial distress semakin rendah. Sebaliknya semakin tinggi nilai TDTA maka probabilitas perusahaan mengalami financial distress semakin tinggi. Tabel berikut menunjukkan hasil pengujian tersebut.

Tabel 5. Variabel dalam Persamaan

\begin{tabular}{lcccc}
\hline \multicolumn{1}{c}{ Variabel } & B & Wald & Sig. & Exp. $($ B) \\
\hline EBITTA & $-19,194$ & 5,898 & 0,001 & 0,000 \\
TDTA & 4,349 & 1,781 & 0,015 & 77,381 \\
C & $-0,728$ & 1,032 & 0,480 & 0,483 \\
\hline
\end{tabular}

Sumber: data sekunder diolah, 2007-2012

\section{Hasil Uji Regresi Logistik Tahun 2008}

Hasil uji Hosmer dan Lemeshow menunjukkan angka di atas 0,05. Dengan demikian data empiris sama dengan model atau model dikatakan fit sehingga dapat diterima. Nilai Nagelkerke R Square menunjukkan angka 0,697. Dengan demikian variabilitas variabel dependen yang dapat dijelaskan oleh variabilitas variabel independen sebesar 69,7\%. Tabel berikut menunjukkan hasil pengujian tersebut. 
Tabel 6. Uji Hosmer dan Lemeshow

\begin{tabular}{lc}
\hline \multicolumn{1}{c}{ Keterangan } & Hasil \\
\hline Nilai Sig. Uji Hosmer dan Lemeshow & 0,889 \\
Nagelkerke R Square & 0,697 \\
\hline
\end{tabular}

Sumber: data sekunder diolah, 2008-2012

Pengujian hipotesis dilakukan dengan melihat hasil yang terdapat dalam Variable in the Equation. Variabel NITA dan WCS signifikan pada 0,05. Semakin tinggi nilai NITA maka probabilitas perusahaan mengalami financial distress semakin rendah. Demikian juga, semakin tinggi nilai WCS maka probabilitas perusahaan mengalami financial distress semakin rendah. Tabel berikut menunjukkan hasil pengujian tersebut.

Tabel 7. Variabel dalam Persamaan

\begin{tabular}{lcccc}
\hline \multicolumn{1}{c}{ Variabel } & B & Wald & Sig. & Exp. $($ B $)$ \\
\hline NITA & $-35,369$ & 11,690 & 0,001 & 0,000 \\
WCS & $-3,545$ & 5,040 & 0,025 & 0,029 \\
C & 2,287 & 12,317 & 0,000 & 9,847 \\
\hline
\end{tabular}

Sumber: data sekunder diolah, 2008-2012

\section{Hasil Uji Regresi Logistik Tahun 2009}

Hasil uji Hosmer dan Lemeshow menunjukkan angka di atas 0,05. Dengan demikian data empiris sama dengan model atau model dikatakan fit sehingga dapat diterima. Nilai Nagelkerke R Square menunjukkan angka 0,820. Dengan demikian variabilitas variabel dependen yang dapat dijelaskan oleh variabilitas variabel independen sebesar $82 \%$. Tabel berikut menunjukkan hasil pengujian tersebut.

\section{Tabel 8. Uji Hosmer dan Lemeshow}

\begin{tabular}{lc}
\hline \multicolumn{1}{c}{ Keterangan } & Hasil \\
\hline Nilai Sig. Uji Hosmer dan Lemeshow & 0,986 \\
Nagelkerke R Square & 0,820 \\
\hline Sumber: data sekunder diolah, 2009-2012
\end{tabular}

Pengujian hipotesis dilakukan dengan melihat hasil yang terdapat dalam Variable in the Equation. Variabel NITA dan TDTA signifikan pada 0,05. Semakin tinggi nilai NITA maka probabilitas perusahaan mengalami financial distress semakin rendah. Sebaliknya, semakin tinggi nilai TDTA maka probabilitas perusahaan mengalami financial distress semakin tinggi. Tabel berikut menunjukkan hasil pengujian tersebut. Sementara itu variabel RETA tidak signifikan pada 0,05. Dengan demikian RETA tidak berpengaruh terhadap prediksi financial distress pada nilai signifikansi 0,05 . 
Tabel 9. Variabel dalam Persamaan

\begin{tabular}{lcccc}
\hline \multicolumn{1}{c}{ Variabel } & B & Wald & Sig. & Exp. $($ B $)$ \\
\hline NITA & $-27,053$ & 6,484 & 0,011 & 0,000 \\
RETA & $-3,897$ & 3,570 & 0,059 & 0,020 \\
TDTA & 8,516 & 7,751 & 0,005 & 4992,007 \\
C & $-1,853$ & 1,498 & 0,221 & 0,157 \\
\hline
\end{tabular}

Sumber: data sekunder diolah, 2009-2012

\section{Hasil Uji Regresi Logistik Tahun 2010}

Hasil uji Hosmer dan Lemeshow menunjukkan angka di atas 0,05. Dengan demikian data empiris sama dengan model atau model dikatakan fit sehingga dapat diterima. Nilai Nagelkerke R Square menunjukkan angka 0,902. Dengan demikian variabilitas variabel dependen yang dapat dijelaskan oleh variabilitas variabel independen sebesar 90,2\%. Tabel berikut menunjukkan hasil pengujian tersebut.

Tabel 10. Uji Hosmer dan Lemeshow

\begin{tabular}{ll}
\hline \multicolumn{1}{c}{ Keterangan } & Hasil \\
\hline Nilai Sig. Uji Hosmer dan Lemeshow & 0,868 \\
Nagelkerke R Square & 0,902 \\
\hline Sumber: data sekunder diolah, 2010-2012
\end{tabular}

Sumber: data sekunder diolah, 2010-2012

Pengujian hipotesis dilakukan dengan melihat hasil yang terdapat dalam Variable in the Equation. Variabel RETA dan TDTA signifikan pada 0,05. Semakin tinggi nilai RETA maka probabilitas perusahaan mengalami financial distress semakin rendah. Sebaliknya, semakin tinggi nilai TDTA maka probabilitas perusahaan mengalami financial distress semakin tinggi. Tabel berikut menunjukkan hasil pengujian tersebut.

Tabel 11. Variabel dalam Persamaan

\begin{tabular}{lcccc}
\hline \multicolumn{1}{c}{ Variabel } & B & Wald & Sig. & Exp. $($ B $)$ \\
\hline RETA & $-16,384$ & 10,299 & 0,001 & 0,000 \\
TDTA & 14,373 & 8,876 & 0,003 & 1745627 \\
C & $-3,380$ & 3,177 & 0,075 & 0,034 \\
\hline
\end{tabular}

Sumber: data sekunder diolah, 2010-2012

\section{Hasil Uji Regresi Logistik Tahun 2011}

Hasil uji Hosmer dan Lemeshow menunjukkan angka di atas 0,05. Dengan demikian data empiris sama dengan model atau model dikatakan fit sehingga dapat diterima. Nilai Nagelkerke R Square menunjukkan angka 0,943. Dengan demikian variabilitas variabel dependen yang dapat dijelaskan oleh variabilitas variabel independen sebesar 94,3\%. Tabel berikut menunjukkan hasil pengujian tersebut. 
Tabel 12. Uji Hosmer dan Lemeshow

\begin{tabular}{lc}
\hline \multicolumn{1}{c}{ Keterangan } & Hasil \\
\hline Nilai Sig. Uji Hosmer dan Lemeshow & 0,925 \\
Nagelkerke R Square & 0,943 \\
\hline Sumber : data sekunder diolah, 2011-2012 &
\end{tabular}

Sumber : data sekunder diolah, 2011-2012

Pengujian hipotesis dilakukan dengan melihat hasil yang terdapat dalam Variable in the Equation. Variabel RETA dan TDTA signifikan pada 0,05. Semakin tinggi nilai RETA maka probabilitas perusahaan mengalami financial distress semakin rendah. Sebaliknya, semakin tinggi nilai TDTA maka probabilitas perusahaan mengalami financial distress semakin tinggi. Tabel berikut menunjukkan hasil pengujian tersebut.

Tabel 13. Variabel dalam Persamaan

\begin{tabular}{lcccc}
\hline \multicolumn{1}{c}{ Variabel } & B & Wald & Sig. & Exp. $($ B) \\
\hline RETA & $-29,279$ & 4,480 & 0,034 & 0,000 \\
TDTA & 27,453 & 4,470 & 0,034 & 836847184077 \\
C & $-5,895$ & 2,123 & 0,145 & 0,003 \\
\hline
\end{tabular}

Sumber: data sekunder diolah, 2011-2012

\section{Hasil Uji Regresi Logistik Tahun Rata-Rata Selama Lima Tahun}

Hasil uji Hosmer dan Lemeshow menunjukkan angka di atas 0,05. Dengan demikian data empiris sama dengan model atau model dikatakan fit sehingga dapat diterima. Nilai Nagelkerke R Square menunjukkan angka 0,768. Dengan demikian variabilitas variabel dependen yang dapat dijelaskan oleh variabilitas variabel independen sebesar 76,8\%. Tabel berikut menunjukkan hasil pengujian tersebut.

Tabel 14. Uji Hosmer dan Lemeshow

\begin{tabular}{ll}
\hline \multicolumn{1}{c}{ Keterangan } & Hasil \\
\hline Nilai Sig. Uji Hosmer dan Lemeshow & 0,561 \\
Nagelkerke R Square & 0,768 \\
\hline Sumber: data sekunder diolah, 2007-2012
\end{tabular}

Sumber: data sekunder diolah, 2007-2012

Pengujian hipotesis dilakukan dengan melihat hasil yang terdapat dalam Variable in the Equation. Variabel EBITTA signifikan pada 0,05. Hal ini berarti semakin tinggi nilai EBITTA maka probabilitas perusahaan mengalami financial distress semakin rendah. Sementara itu, CFTD tidak signifikan pada 0,05. Dengan demikian dengan nilai signifikansi sebesar 0,05 CFTD tidak berpengaruh terhadap prediksi financial distress.

Tabel 15. Variabel dalam Persamaan

\begin{tabular}{lcccc}
\hline \multicolumn{1}{c}{ Variabel } & B & Wald & Sig. & Exp. (B) \\
\hline EBITTA & $-42,038$ & 14,925 & 0,000 & 0,000 \\
CFTD & $-5,765$ & 3,340 & 0,068 & 0,003 \\
C & 3,914 & 15,134 & 0,000 & 50,102 \\
\hline
\end{tabular}

Sumber: data sekunder diolah, 2007-2012 


\section{Kesimpulan Hasil Regresi}

Tabel berikut menunjukkan kesimpulan hasil atas variabel-variabel yang berpengaruh signifikan terhadap prediksi financial distress berdasarkan periode. Dapat disimpulkan terdapat tiga rasio yang bersifat konsisten dalam memprediksi financial distress dengan menggunakan Altman Z-Score, yakni rasio yang terkait dengan akumulasi laba, nilai hutang, dan kemampuan perusahaan dalam menghasilkan laba. Rasio-rasio tersebut meliputi RETA, TDTA, EBITTA, dan NITA.

Tabel 16. Kesimpulan Hasil Regresi

\begin{tabular}{clllllll}
\hline No & \multicolumn{1}{c}{ Rasio } & \multicolumn{5}{c}{ Periode } \\
& & $\mathbf{2 0 0 7}$ & $\mathbf{2 0 0 8}$ & $\mathbf{2 0 0 9}$ & $\mathbf{2 0 1 0}$ & $\mathbf{2 0 1 1}$ & Rata2 \\
\hline 1. & NITA & & & & & \\
2. & RETA & & & & & \\
3. & EBITTA & & & & & \\
4. & TDTA & & & & & \\
5. & WCS & & & & \\
& : berpengaruh & & & & \\
\end{tabular}

Sumber: data sekunder diolah, 2007-2012

RETA dan TDTA secara konsisten dapat digunakan untuk mengestimasi kondisi financial distress berturut-turut selama tiga tahun sebelum prediksi. Pengaruh kedua variabel terhadap prediksi financial distress diawali oleh besarnya nilai hutang dan kemampuan perusahaan dalam menghasilkan laba. Nilai hutang yang tinggi diikuti dengan ketidakmampuan perusahaan dalam menghasilkan laba dapat berpengaruh terhadap penurunan akumulasi laba perusahaan disertai dengan peningkatan nilai hutang, yang pada akhirnya berdampak terhadap prediksi financial distress.

Secara berturut-turut tiga tahun sebelum prediksi menunjukkan bahwa rasio RETA dan TDTA berpengaruh terhadap prediksi financial distress. Tiga tahun sebelum prediksi untuk rasio TDTA perusahaan-perusahaan yang tergolong sehat terjadi penurunan, sementara untuk perusahaan-perusahaan yang tidak sehat terjadi kenaikan. Demikian pula dengan rasio RETA. Namun nilai rata-rata untuk kedua rasio ini selama lima tahun menunjukkan pengaruh yang tidak signifikan. Hal ini mengindikasikan adanya bias ketika kedua rasio tersebut dirata-rata sehingga penggunaan nilai rata-rata jangka panjang RETA dan TDTA tidak tepat untuk prediksi, kecuali dalam periode di mana kondisi keuangan perusahaan dalam keadaan konstan.

Sementara itu untuk rasio keuangan yang berkaitan dengan kemampuan perusahaan dalam menghasilkan laba menunjukkan hanya rasio EBITTA tahun 2007 yang berpengaruh terhadap prediksi financial distress, sementara di tahun 2008 hingga 2011 menunjukkan tidak adanya pengaruh. Untuk rasio rata-rata EBITTA selama lima tahun terbukti berpengaruh. Hal ini mengindikasikan adanya manajemen 
laba yang dilakukan. Nilai rata-rata EBITTA berpengaruh signifikan menunjukkan bahwa rata-rata EBITTA dalam jangka panjang dapat digunakan untuk memprediksi financial distress karena periode yang panjang dapat meminimalkan pengaruh manajemen laba.

Rasio NITA tiga hingga empat tahun sebelum prediksi menunjukkan pengaruh signifikan. Hal ini membuktikan bahwa rasio yang mencerminkan laba dapat menjadi sinyal terhadap prediksi financial distress. Nilai rata-rata NITA yang tidak menunjukkan pengaruh signifikan juga mengindikasikan adanya manajemen laba yang berdampak terhadap rasio NITA jangka panjang yang belum dapat terpulihkan.

Dengan demikian terdapat perbedaan hasil antara rasio EBITTA maupun NITA dalam memprediksi financial distress. Hal ini mengindikasikan kemungkinan penggunaan proksi bagi prediksi financial distress yang kurang tepat untuk diterapkan dalam perusahaan sampel.

Hanya periode empat tahun sebelum prediksi menunjukkan bahwa rasio WCS berpengaruh signifikan. Hal ini menunjukkan bahwa komponen hutang lancar kurang tepat digunakan untuk memprediksi financial distress. Hal ini disebabkan karena financial distress lebih diakibatkan oleh dampak dari keberadaan hutang jangka panjang. Selain itu, komponen yang mencerminkan likuiditas tidak hanya dipengaruhi oleh kas namun juga dipengaruhi oleh komponen aset-aset lancar lainnya.

\section{Hasil Uji Beda Closing Price terhadap Prediksi Financial Distress}

Hasil uji normalitas terhadap variabel closing price menunjukkan bahwa data closing price bersifat tidak normal dengan nilai signifikansi 0,000. Hasil uji beda dengan Kruskall-Wallis menunjukkan nilai signifikansi 0,000, di bawah 0,005 maka hipotesis yang menyatakan bahwa terdapat perbedaan reaksi investor terhadap prediksi financial distress tidak dapat ditolak. Dengan demikian investor dapat membedakan antara perusahaan-perusahaan yang mengalami financial distress dengan yang tidak.

\section{KESIMPULAN}

Berdasarkan hasil dan pembahasan, maka dapat dirumuskan suatu kesimpulan sebagai berikut :

1. Rasio-rasio keuangan yang mencerminkan akumulasi kemampuan menghasilkan laba, nilai hutang, dan kemampuan perusahaan dalam menghasilkan laba itu sendiri merupakan faktor yang dominan dalam memprediksi financial distress. Rasio-rasio tersebut meliputi RETA, TDTA, EBITTA, dan NITA.

2. Untuk prediksi financial distress rasio yang mencerminkan laba dengan periode panjang sebaiknya digunakan nilai rata-rata untuk meminimalkan pengaruh manajemen laba, namun rasio hutang maupun akumulasi laba sebaiknya dengan melihat nilai rasio per tahun. 
3. Risiko bisnis dan ukuran perusahaan tidak terbukti sebagai variabel yang dapat memprediksi financial distress.

4. Investor dapat memprediksi financial distress. Hal ini ditunjukkan dari adanya perbedaan reaksi investor antara perusahaan yang diprediksi mengalami financial distress dengan yang tidak. 


\section{DAFTAR PUSTAKA}

Altman, E. 1968. Financial Ratios, Discriminant Analysis, and the Prediction of Corporate Bankruptcy. The Journal of Finance. Vol. XXIII, No. 4, p. 589 609.

Almilia, LS dan Kristijadi. 2003. Analisis Rasio Keuangan untuk Memprediksi Kondisi Financial Distress Perusahaan Manufaktur yang Terdaftar di Bursa Efek Jakarta. JAAI. Vol. 7, No. 2, h. 183 - 208.

Almilia, LS. 2006. Prediksi Kondisi Financial Distress Perusahaan Go Public dengan Menggunakan Analisis Multinomial Logit. Jurnal Ekonomi dan Bisnis. Vo. XII, No. 1, h. $1-26$.

Brahmana, RK. 2003. Identifying Financial Distress Condition in Indonesia Manufacture Industry. Birmingham Business School, University of Birmingham. United Kingdom.

Brigham dan Houston. 2006. Dasar-dasar Manajemen Keuangan (Fundamentals of Financial Management). Buku 1. Edisi 10. Salemba Empat. Jakarta.

Ghozali, I. 2007. Aplikasi Analisis Multivariate dengan Program SPSS. Badan Penerbit Universitas Diponegoro. Semarang.

Hanafi, MM dan A. Halim. 2007. Analisis Laporan Keuangan. Edisi 3. UPP STIM YKPN. Yogyakarta.

Hardianti, S dan Barbara Gunawan. 2010. Pengaruh Size, Likuiditas, Profitabilitas, Risiko, dan Pertumbuhan terhadap Struktur Modal pada Perusahaan Manufaktur di Bursa Efek Indonesia. Jurnal Akuntansi dan Investasi. Vol. 11, No. 2.

Kamaludin dan KA Pribadi,. 2011. Prediksi Financial Distress Kasus Industri Manufaktur Pendekatan Model Regresi Logistik. Forum Bisnis dan Kewirausahaan Jurnal Ilmiah STIE MDP. Vol. 1, No. 1, h. 11 - 23.

Parwati, LA dan Y. Suhardjo. 2009. Faktor-faktor yang Mempengaruhi Audit Delay. Solusi. Vol. 8, No. 3, h. $29-42$.

Ramadhani, AS dan N. Lukviarman. 2009. Perbandingan Analisis Prediksi Kebangkrutan Menggunakan Model Altman Pertama, Altman Revisi, dan Altman Modifikasi dengan Ukuran dan Umur Perusahaan Sebagai Variabel Penjelas (Studi pada Perusahaan Manufaktur yang Terdaftar di Bursa Efek Indonesia. Jurnal Siasat Bisnis. Vol. 13, No. 1, h. 15 - 28.

Terzi, et. al. 2012. Comparison of Financial Distress Prediction Models : Evidence from Turkey. European Journal of Social Sciences. Vol. 32, No. 4, p. 607 618.

Yap, et. al. 2012. Evaluating Company Failure in Malaysia Using Financial Ratios and Logistic Regression. Asian Journal of Finance \& Accounting. Vol. 4, No. 1, p. $330-344$.

Yuanita, I. 2010. Prediksi Financial Distress dalam Industri Textile dan Garment. Jurnal Akuntansi \& Manajemen. Vol. 5, No. 1, h. 101-119. 